\title{
IMPLEMENTASI METODE TOPSIS UNTUK PEMILIHAN WISUDAWAN TERBAIK
}

\author{
Felix Andreas Sutanto', Heribertus Yulianton ${ }^{2}$, Kristophorus Hadiono ${ }^{3}$ \\ ${ }^{1,2}$ Program Studi Teknik Informatika, ${ }^{3}$ Program Studi Sistem Informasi \\ Fakultas Teknologi Informasi, Universitas Stikubank \\ ${ }^{1}$ felix@edu.unisbank.ac.id, ${ }^{2}$ heri@edu.unisbank.ac.id, \\ ${ }^{3}$ kristophorus.hadiono@edu.unisbank.ac.id
}

\begin{abstract}
Abstrak
Kelulusan merupakan hal yang pasti terjadi dalam akhir proses sebuah pendidikan. Mendapatkan predikat wisudawan terbaik merupakan kebanggaan tersendiri bagi mahasiswa diakhir masa studinya. Fakultas Teknologi Informasi Universitas Stikubank, setiap semester selalu dihadapkan pada proses tersebut. Penetapan wisudawan terbaik dari FTI Unisbank memiliki lebih dari satu kriteria yaitu Indeks Prestasi Kumulatif (IPK), Nilai Prestasi yang diperoleh dari Kartu Rencana Prestasi (KRP), masa studi siswa yang bersangkutan, dan sertifikasi kompetensi atau sertifikasi pelatihan bertaraf internasional. Metode yang digunakan untuk membantu menentukan wisudawan terbaik adalah metode TOPSIS. Pemilihan metode tersebut karena beberapa alasan salah satunya adalah kemudahan penerapan. Implementasi metode TOPSIS atas masalah tersebut diterapkan dengan membuat sebuah aplikasi berbasis web. Hasil yang diperoleh dengan menerapkan metode TOPSIS, adalah alternatif/wisudawan yang memiliki skor tertinggi dari hasil perhitungan akhir.
\end{abstract}

Kata Kunci: implementasi, metode TOPSIS, kelulusan, multi criteria decision making

\section{PENDAHULUAN}

Kelulusan merupakan hal yang pasti terjadi dalam akhir proses pendidikan. Proses kelulusan biasanya ditandai dengan terpenuhinya persyaratan yang sudah ditetapkan oleh penyelenggara pendidikan oleh siswa yang bersangkutan. Persyaratan kelulusan siswa dapat bermacam-macam bentuknya dan berkarakteristik sesuai dengan karakter lembaga pendidikan serta dapat berbentuk akademik dan non-akademik. Kelulusan selalu berhubungan dengan wisuda. Yang berhak untuk mengikuti wisuda adalah siswa yang telah menyelesaiakan segala persyaratan kelulusan.

Dalam acara tersebut, sebagai bentuk penghargaan, biasanya siswa yang memiliki prestasi terbaik diberi penghargaan sebagai lulusan terbaik pada masanya. Pemberian penghargaan kepada siswa yang memiliki prestasi terbaik merupakan sebuah proses yang tidak mudah karena kriteria yang harus dipenuhi berjumlah lebih dari satu.

Fakultas Teknologi Informasi (FTI) Universitas Stikubank (Unisbank), selalu mengadakan pemilihan wisudawan terbaik setiap kali wisuda. Penetapan wisudawan terbaik dari FTI Unisbank memiliki lebih dari satu kriteria. Kriteria yang digunakan adalah Indeks Prestasi Kumulatif (IPK), Nilai Prestasi yang diperoleh dari Kartu Rencana Prestasi (KRP), masa studi siswa yang bersangkutan, dan sertifikasi kompetensi atau sertifikasi pelatihan bertaraf internasional. Karena jumlah siswa yang harus dinilai berjumlah banyak, maka pengambilan keputusan siapa yang berhak untuk menyandang penghargaan wisudawan terbaik dapat menjadi masalah yang pelik. Kondisi peliknya pengambilan keputusan dapat terminimalisir dengan memanfaatkan metode-metode yang secara ilmiah sudah terbukti membantu seseorang untuk mengambil keputusan.

Ada banyak metode yang dapat digunakan untuk membantu mengambil keputusan dimana ada lebih dari satu syarat yang harus dipenuhi saat keputusan tersebut diambil. Salah 
satu metode yang dapat dimanfaatkan adalah Technique for Order Preference by Similarity to Ideal Solution (TOPSIS). TOPSIS dapat dijelaskan sebagai sebuah metode yang akan mencari alternatif terbaik dimana alternatif tersebut memiliki jarak terdekat/terkecil dari solusi positif yang ideal, serta memiliki jarak terjauh dari solusi negatif yang diukur dari sudut pandang perhitungan geometris. Sehingga inti masalah yang dibahas dalam artikel ini adalah penerapan metode TOPSIS untuk membantu memilih lulusan terbaik dengan kriteria Indeks Prestasi Kumulatif (IPK), Nilai Prestasi yang diperoleh dari Kartu Rencana Prestasi (KRP), masa studi siswa yang bersangkutan, dan sertifikasi kompetensi atau sertifikasi pelatihan bertaraf internasional.

Ruang lingkup pembahasan artikel ini hanya terbatas pada persyaratan kelulusan yang ditetapkan oleh FTI Unisbank dengan alternatifnya berasal dari siswa/mahasiswa dari FTI Unisbank yang sudah dinyatakan lulus. Pembahasan artikel ini mengikuti alur seperti berikut, bagian pertama adalah pendahuluan yang berisi pengantar mengenai permasalahan dan ruang lingkup permasalahan yang akan dibahas dalam penelitian, bagian kedua berisi mengenai tinjauan pustakan yang berkaitan dengan pemanfaatan metode TOPSIS dalam pengambilan keputusan, dan bagian ketiga merupakan bagian terakhir yang berisi mengenai implementasi dari TOPSIS, pembahasan serta kesimpulan.

\section{TINJAUAN PUSTAKA}

Pemanfaatan metode pengambilan keputusan yang dapat dipertanggungjawabkan secara ilmiah merupakan sebuah kebutuhan yang mutlak. Dikatakan mutlak karena saat seseorang harus mengambil keputusan, keputusan tersebut harus dapat dipertanggjawabkan. Keputusan yang diambil tidak boleh berdasarkan perasaan suka atau tidak suka, tetapi harus benar-benar obyektif.

Secara historis, metode TOPSIS dikembangkan pertama kali oleh Yoon dan Hwang [1] Konsep dasar dari metode tersebut adalah bahwa alternatif terbaik yang dipilih harus memiliki jarak terdekat dari solusi ideal positif dan sekaligus memiliki jarak terjauh dari solusi ideal negatif dengan memanfaatkan perhitungan Euclidean.

Memanfaatkan metode TOPSIS [2] untuk memilih kondisi optimal dari operasi pendinginan dengan menggunakan menara pendingin. Dari 9 (sembilan) kombinasi alternatif yang ada, setelah dihitung menggunakan metode TOPSIS, dihasilkan 9 (sembilan) kemungkinan terurut mulai dari kombinasi yang terbaik sampai terjelek. Proses penerapan perhitungan kombinasi pendinginan dan penerapan metode TOPSIS dilakukan dengan memanfaatkan software Matlab. Hasil penelitian tersebut mengindikasikan bahwa penerapan metode TOPSIS setelah melakukan perhitungan kemungkinan kombinasi pendiginan yang dapat dilakukan, memberikan hasil yang baik.

Metode TOPSIS [3] yang dimodifikasi dengan menambahkan fuzzy pada metode tersebut untuk menentukan kombinasi optimal dari komposit yang mudah terurai (biodegradable). Metode fuzzy TOPSIS diterapkan untuk memperoleh performa terbaik dari material komposit yang mudah terurai. Hasilnya, kombinasi material yang memiliki kandungan serat, PCL, graphite dan matrix merupakan alternatif terbaik dibandingkan kombinasi material lainnya.

Menggunakan metode TOPSIS [4] yang digabungkan dengan metode fuzzy untuk pemilihan spillway (struktur yang dimanfaatkan untuk pelepasan aliran yang terkontrol dari bendungan atau tanggul menuju daerah hilir) untuk sebuah bendungan di distrik Kilkis yang terletak di utara Yunani. Pemilihan spillway yang optimal akan memberikan efek yang signifikan terhadap konstruksi dari sebuah bendungan. Digunakannya metode TOPSIS berdasarkan pertimbangan bahwa metode tersebut mampu memberikan solusi optimal terhadap pemilihan spillway dimana kondisi pemilihan spillway memiliki syarat yang cukup kompleks. 
Meskipun metode TOPSIS yang digunakan digabungkan dengan metode fuzzy, hasil yang diperoleh tidak mengurangi kemampuan metode TOPSIS untuk memberikan hasil yang optimal dalam pemilihan spillway yang dibutuhkan.

Dari beberapa penelitian terdahulu, dapat disimpulkan bahwa metode TOPSIS dapat memberikan bantuan dalam pengambilan keputusan secara praktis, karena metode tersebut memiliki konsep yang sederhana dan mudah penerapannya. Atas dasar inilah, dalam penelitian ini metode TOPSIS digunakan untuk memberikan bantuan dalam menentukan wisudawan terbaik.

\section{METODE PENELITIAN}

Metode penelitian yang digunakan dalam penelitian ini dibagi menjadi dua bagian, yaitu (a) pengumpulan data, dan (b) pengembangan sistem. Obyek dari penelitian ini adalah mahasiswa yang dinyatakan lulus oleh FTI Unisbank. Untuk pengumpulan data, peneliti melakukan observasi terhadap obyek penelitian dan juga melakukan studi kepustakaan terhadap pemanfaat metode pengambilan keputusan. Dalam metode pengembangan sistem, peneliti menerapkan langkah-langkah: (1) Analisis; (2) Desain; (3) Implementasi; (4) Testing.

Untuk menerapkan metode TOPSIS, langkah-langkah yang harus dilakukan adalah:

a. Membuat matrik evaluasi yang terdiri dari $m$ alternatif dan $n$ kriteria, dimana irisan antara alternatif dan kriteria yang disimbolkan dengan $\chi_{i j}$, sehingga

$$
\left(\chi_{i j}\right)_{m x n} \text { atau } \chi_{i j}=\left[\begin{array}{cccc}
y_{11} & y_{12} & \cdots & y_{1 j} \\
y_{21} & y_{22} & \cdots & y_{2 j} \\
\vdots & \vdots & \ddots & \vdots \\
y_{i 1} & y_{i 2} & \cdots & y_{i j}
\end{array}\right]
$$

b. Matrik evaluasi tersebut kemudian dinormalisasi dengan persamaan sebagai berikut

$$
R=\left(r_{i j}\right)_{m x n} \operatorname{dimana} r_{i j}=\frac{\chi_{i j}}{\sqrt{\sum_{k=1}^{m} x_{k j}^{2}}}, i=1,2, \ldots, m, j=1,2, \ldots, n
$$

c. Setelah dinormalisasi, langkah selanjutnya adalah menghitung bobot matrik yang ternormalisasi dengan persamaan,

$t_{i j}=r_{i j} \cdot w_{j}, i=1,2, \ldots, m, j=1,2, \ldots, n$ dimana

$w_{j}=W_{j} / \sum_{k=1}^{n} W_{k}, j=1,2, \ldots, n$ sehingga

$\sum_{i=1}^{n} w_{i}=1$ dan $W_{j}$ adalah bobot asli yang berasal dari indikator $v_{j}, j=1,2, \ldots, n$.

d. Langkah selanjutnya adalah menentukan alternatif terburuk dan alternatif terbaik dengan persamaan,

$$
\begin{aligned}
& A_{w}=\left\{\left\langle\max \left(t_{i j} \mid i=1,2, \ldots, m\right) \mid j \in J_{-}\right\rangle,\left\langle\min \left(t_{i j} \mid i=1,2, \ldots, m\right) \mid j \in J_{+}\right\rangle\right\} \equiv \\
& \left\{t_{w j} \mid j=1,2, \ldots, n\right\} \\
& \text { dan }
\end{aligned}
$$

$A_{b}=\left\{\left\langle\min \left(t_{i j} \mid i=1,2, \ldots, m\right) \mid j \in J_{-}\right\rangle,\left\langle\max \left(t_{i j} \mid i=1,2, \ldots, m\right) \mid j \in J_{+}\right\rangle\right\} \equiv$

$\left\{t_{b j} \mid j=1,2, \ldots, n\right\}$

dimana

$J_{+}=\{j=1,2, \ldots, n \mid j\}$ dan $J_{-}=\{j=1,2, \ldots, n \mid j\}$

e. Kemudian menghitung jarak antara target alternatif ke $i$ dengan kondisi terburuk $A_{w}$ dan kondisi terbaik $A_{b}$ dengan persamaan

$d_{i w}=\sqrt{\sum_{i=1}^{n}\left(t_{i j}-t_{w j}\right)^{2}}, i=1,2, \ldots$, muntuk kondisi terburuk

dan 
$d_{i b}=\sqrt{\sum_{j=1}^{n}\left(t_{i j}-t_{b j}\right)^{2}}, j=1,2, \ldots$, muntuk kondisi terbaik

f. Langkah selanjutnya adalah menghitung kesamaan dengan kondisi terburuk melalui persamaan

$s_{i w}=d_{i w} /\left(d_{i w}+d_{i b}\right), 0 \leqslant s_{i w} \leqslant 1, i=1,2, \ldots$, mdimana

$s_{i w}=1$ jika dan hanya jika solusi alternatifnya memiliki kondisi terbaik, dan

$s_{i w}=0$ jika dan hanya jika solusi alternatifnya memiliki kondisi terburuk.

g. Langkah terakhir adalah mengurutkan alternatifnya berdasarkan persamaan

$s_{i w}(i=1,2, \ldots, m)$ atau dengan kata lain diurutkan dari nilai yang tertinggi.

Kriteria yang akan digunakan pada penelitian ini diambil berdasarkan kriteria penentuan wisudawan terbaik di FTI Unisbank. Kriteria tersebut adalah Indeks Prestasi Kumulatif (IPK) terbaik, Nilai Prestasi yang berasalah dari Kartu Rencana Prestasi (KRP), masa studi siswa yang bersangkutan, dan sertifikasi kompetensi atau sertifikasi pelatihan bertaraf internasional. Dari kriteria tersebut, dibuatlah bobot dan skor agar dapat digunakan pada metode TOPSIS. Pengaturan skor untuk IPK, KRP dan Kejuaraan berdasar pada Buku Pedoman Akademik dan Buku Panduan SKP. Sedangkan untuk sertifikasi diatur menyesuaikan kebijakan fakultas. Berikut ini adalah daftar bobot (tabel 1) dan skor (tabel 2) dari kriteria yang akan digunakan dalam penelitian ini.

Tabel 1. Bobot Kriteria

\begin{tabular}{|l|l|c|}
\hline No. & \multicolumn{1}{|c|}{ Kriteria } & Bobot \\
\hline C1 & IPK & $40 \%$ \\
\hline C2 & KRP & $30 \%$ \\
\hline C3 & Sertifikasi & $30 \%$ \\
\hline C4 & Kejuaraan & $10 \%$ \\
\hline
\end{tabular}

Tabel 2. Skor Kriteria

\begin{tabular}{|c|l|c|}
\hline Kriteria & \multicolumn{1}{|c|}{ Data Awal } & Konversi \\
\hline $\mathrm{C} 1$ & $2,75-3,00$ & 1 \\
\hline & $3,01-3,60$ & 2 \\
\hline & $3,61-4,00$ & 3 \\
\hline $\mathrm{C} 2$ & $100-150$ & 1 \\
\hline & $151-200$ & 2 \\
\hline & $201-250$ & 3 \\
\hline $\mathrm{C} 3$ & 1 Sertifikasi & 1 \\
\hline & 1 Sertifikasi + Gelar & 2 \\
\hline & 2 Sertifikasi & 3 \\
\hline & 2 Sertifikasi + Gelar & 4 \\
\hline & 3 Sertifikasi & 5 \\
\hline & 3 Sertifikasi + Gelar & 6 \\
\hline C4 & Tidak ada & 1 \\
\hline & Unisbank & 2 \\
\hline & Kota & 3 \\
\hline & Propinsi & 4 \\
\hline & Nasional & 5 \\
\hline & Internasional & 6 \\
\hline
\end{tabular}


Dalam mengolah data mahasiswa yang sudah dinyatakan lulus, untuk mendapatkan mahasiswa yang akan memperoleh gelar wisudawan terbaik, langkah-langkah yang dilakukan adalah sebagai berikut:

a. Menentukan data alternatif atau data wisudawan yang akan dipilih sebagai wisudawan terbaik.

b. Mengkonversi data tersebut menjadi nilai alternatif pada setiap kriteria

c. Menentukan matrik ternormalisasi dari data nilai alternatif

d. Melakukan perhitungan pembobotan kriteria

e. Menentukan matrik solusi ideal positif dan negatif

f. Menentukan nilai preferensi dari setiap kriteria

Sesuai dengan langkah-langkah yang sudah ditetapkan, proses selanjutnya setelah semua komponen yang diperlukan untuk menerapkan metode TOPSIS tersedia, adalah menyiapkan data alternatif (calon mahasiswa yang berhak mendapatkan gelar wisudawan terbaik) (tabel 3).

Tabel 3. Data Alternatif

\begin{tabular}{|c|c|c|c|c|}
\hline \multirow{2}{*}{ Alternatif } & C1 & C2 & C3 & C4 \\
\hline A1 & 3,61 & 200 & 3 & 0 \\
\hline A2 & 3,72 & 155 & $3+\mathrm{G}$ & 0 \\
\hline A3 & 3,75 & 205 & $3+\mathrm{G}$ & Unisbank \\
\hline A4 & 3,65 & 215 & 3 & 0 \\
\hline A5 & 3,8 & 215 & 3 & 0 \\
\hline
\end{tabular}

Dari tabel 3, proses yang harus dilakukan selanjutnya adalah melakukan normalisasi, tetapi data pada tabel 3 masih belum sama jenisnya sehingga diperlukan langkah konversi untuk mendapatkan skor kriteria. Dasar konversi untuk mendapatkan skor kriteria seperti yang terdapat pada tabel 2, sehingga data pada tabel 3 setelah di konversi akan menjadi seperti pada tabel 4.

Tabel 4. Konversi Nilai

\begin{tabular}{|c|c|c|c|c|}
\hline Alternatif & C1 & C2 & C3 & C4 \\
\hline A1 & 3 & 2 & 5 & 1 \\
\hline A2 & 3 & 2 & 6 & 1 \\
\hline A3 & 3 & 3 & 6 & 1 \\
\hline A4 & 3 & 3 & 5 & 1 \\
\hline A5 & 3 & 3 & 5 & 2 \\
\hline
\end{tabular}

Dari tabel 4, proses normalisasi baru dapat dilakukan dan proses normalisasi ini berlaku pada tabel alternatif serta tabel kriteria. Hasil normalisasi dapat dilihat pada tabel 5 dan tabel 6 berikut ini.

Tabel 5. Matrik Ternormalisasi

\begin{tabular}{|c|c|c|c|}
\hline $\mathrm{X} 1$ & $\mathrm{X} 2$ & $\mathrm{X} 4$ & $\mathrm{X} 4$ \\
\hline 6,708 & 6,325 & 12,124 & 2,828 \\
\hline
\end{tabular}


Tabel 6. Matrik Ternormalisasi Alternatif

\begin{tabular}{|c|c|c|c|c|}
\hline Alternatif & C1 & C2 & C3 & C4 \\
\hline Normalisasi & R1 & R2 & R3 & R4 \\
\hline A1 & 0,447 & 0,316 & 0,412 & 0,354 \\
\hline A2 & 0,447 & 0,474 & 0,494 & 0,354 \\
\hline A3 & 0,447 & 0,474 & 0,494 & 0,354 \\
\hline A4 & 0,447 & 0,474 & 0,412 & 0,354 \\
\hline A5 & 0,447 & 0,474 & 0,412 & 0,707 \\
\hline
\end{tabular}

Proses selanjutnya adalah membuat hasil dari tabel 6 menjadi matrik normalisasi yang sudah terbobot. Hasil nya dapat dilihat pada tabel 7 berikut ini.

Tabel 7. Normalisasi Terbobot

\begin{tabular}{|c|c|c|c|c|}
\hline Alternatif & C1 & C2 & C3 & C4 \\
\hline $\begin{array}{c}\text { Kriteria } \\
\text { terbobot }\end{array}$ & Y1 & Y2 & Y3 & Y4 \\
\hline A1 & 1,789 & 0,949 & 0,825 & 0,354 \\
\hline A2 & 1,789 & 1,423 & 0,990 & 0,354 \\
\hline A3 & 1,789 & 1,423 & 0,990 & 0,354 \\
\hline A4 & 1,789 & 1,423 & 0,825 & 0,354 \\
\hline A5 & 1,789 & 1,423 & 0,825 & 0,707 \\
\hline
\end{tabular}

Langkah berikutnya adalah menentukan matrik solusi ideal positif dan negatif yang didapatkan dari nilai maksimal normalisasi terbobot dan nilai minimal normalisasi terbobot. Hasil perhitungan untuk langkah ini disajikan pada tabel 8 beirkut ini.

Tabel 8. Solusi Ideal Positif dan Negatif

\begin{tabular}{|c|c|c|c|c|}
\hline Alternatif & $\mathrm{C} 1$ & $\mathrm{C} 2$ & $\mathrm{C} 3$ & $\mathrm{C} 4$ \\
\hline $\mathrm{A}+$ & 1,789 & 1,423 & 0,990 & 0,707 \\
\hline $\mathrm{A}-$ & 1,789 & 0,949 & 0,825 & 0,354 \\
\hline
\end{tabular}

Dari tabel 8, baru dapat dihitung jarak antara nilai setiap alternatif dengan data yang terdapat pada tabel 8 . Hasil perhitungannya disajikan pada tabel 9.

Tabel 9. Jarak Matrik

\begin{tabular}{|c|c|c|c|}
\hline $\begin{array}{c}\text { Jarak } \\
\text { Alternatif }\end{array}$ & Positif(+) & Negatif(-) & D+ + D- \\
\hline A1 & 0,614 & 0 & 0,614 \\
\hline A2 & 0,354 & 0,502 & 0,856 \\
\hline A3 & 0,354 & 0,502 & 0,856 \\
\hline A4 & 0,390 & 0,474 & 0,865 \\
\hline A5 & 0,165 & 0,592 & 0,757 \\
\hline
\end{tabular}


Sehingga nilai preferensi didapat dari solusi ideal negatif (D-) dibagi dengan jumlah solusi ideal positif dan negatif (D+ + D-) yang disajikan seperti pada tabel 10 .

Tabel 10. Hasil Preferensi

\begin{tabular}{|c|c|}
\hline Alternatif & V \\
\hline A1 & 0 \\
\hline A2 & 0,587 \\
\hline A3 & 0,587 \\
\hline A4 & 0,547 \\
\hline A5 & 0,782 \\
\hline
\end{tabular}

Dari tabel 10, dapat disimpulkan bahwa wisudawan terbaik dari 5 alternatif yang ada adalah alternatif 5 (A5) dengan skor 0.782 .

\section{HASIL DAN PEMBAHASAN}

Implementasi penentuan wisudawan terbaik dengan memanfaatkan metode TOPSIS, dibuat menjadi sebuah aplikasi berbasis web. Aplikasi tersebut memiliki beberapa bagian, yaitu kriteria, alternatif, nilai matrik dan perhitungan TOPSIS. Berikut ini merupakan tampilan bagian alternatif (gambar 1).

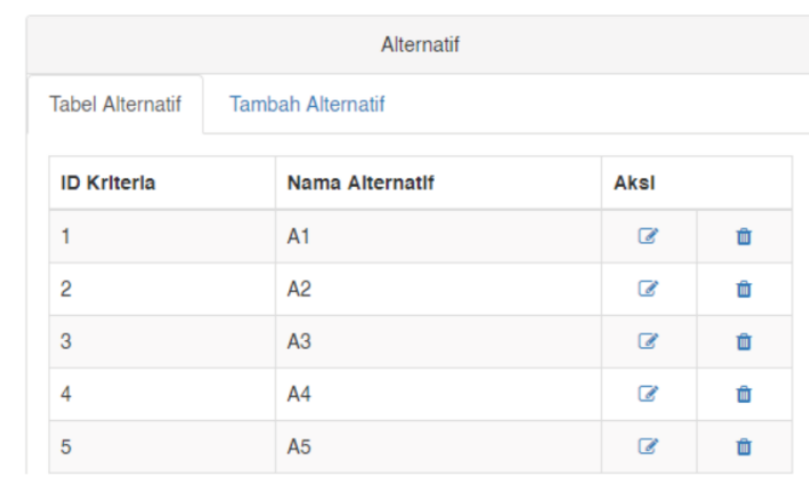

Gambar 1. Tampilan Bagian Alternatif.

Halaman/tampilan gambar 1 digunakan untuk mengelola data alternatif atau wisudawan, halaman ini dilengkapi dengan fasilitas untuk edit dan hapus data.

Selanjutnya adalah halaman untuk bagian kriteria yang dapat dilihat seperti gambar 2 . Halaman ini digunakan untuk mengelola data kriteria.

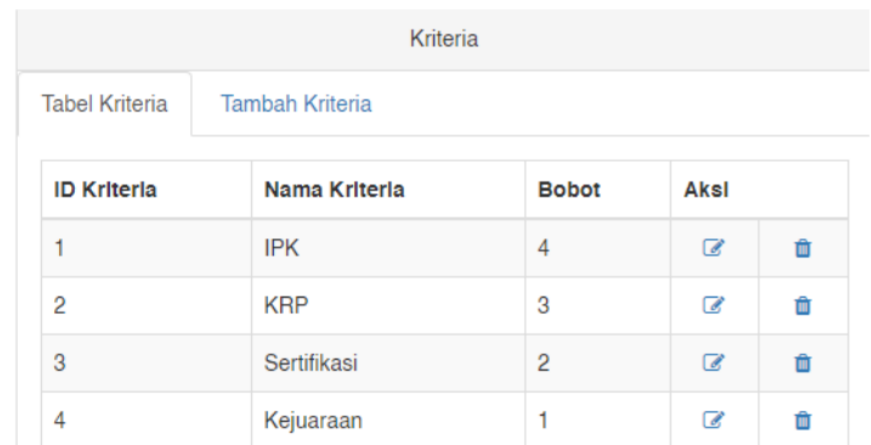

Gambar 2. Tampilan Bagian Kriteria. 
Halaman input nilai matrik merupakan bagian yang digunakan untuk memasukan nilai kriteria untuk alternatif yang ada (gambar 3).

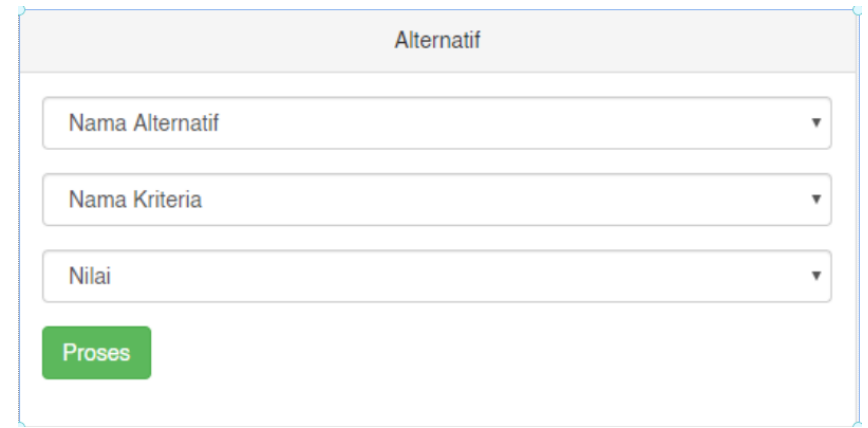

Gambar 3. Tampilan Input Nilai untuk Alternatif.

Setelah semua komponen yang dibutuhkan tersedia, proses selanjutnya adalah menghitung proses yang terdapat pada metode TOPSIS. Beberapa gambar berikut ini merupakan contoh tampilan yang dibuat untuk melihat hasil perhitungan yang dilakukan.

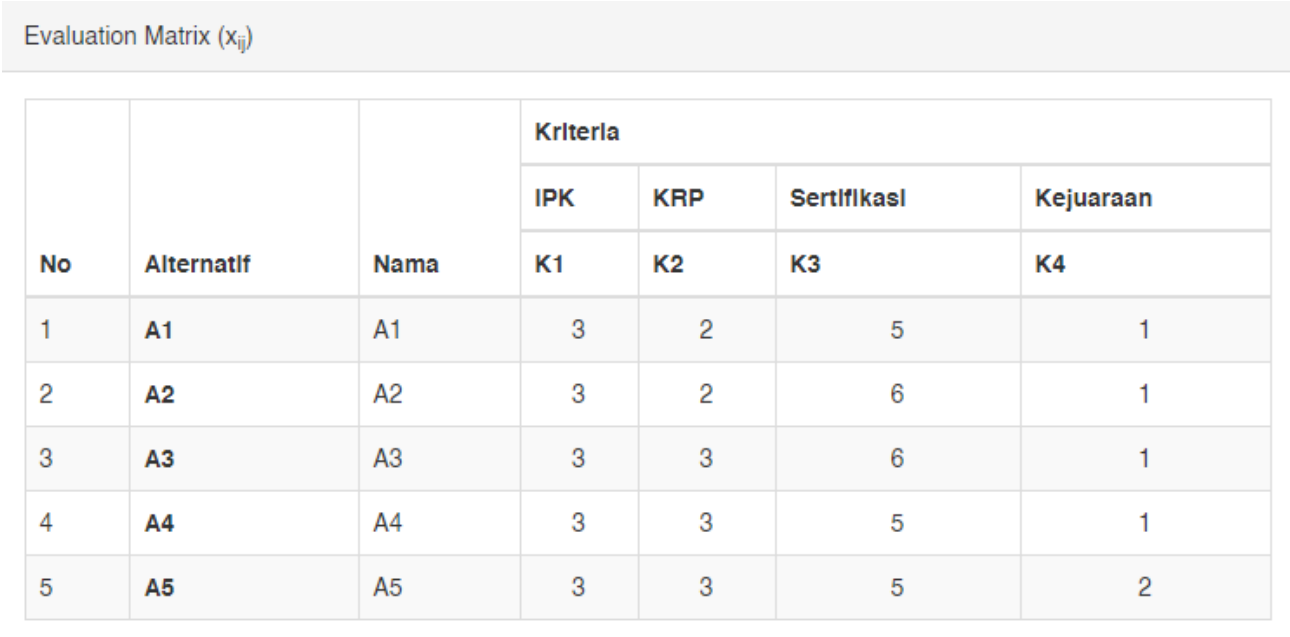

Gambar 4. Hasil / Tampilan Matrik Evaluasi.

\begin{tabular}{|c|c|c|c|c|c|c|}
\hline Ratin & nerja Ternorn & $i\left(r_{i i}\right)$ & & & & \\
\hline \multirow[b]{3}{*}{ No } & \multirow[b]{3}{*}{ Alternatlf } & \multirow[b]{3}{*}{ Nama } & \multicolumn{4}{|l|}{ Kriterla } \\
\hline & & & IPK & KRP & Sertlflkasl & Kejuaraan \\
\hline & & & K1 & K2 & K3 & K4 \\
\hline 1 & A1 & $\mathrm{A} 1$ & 0.4472 & 0.3381 & 0.4124 & 0.3536 \\
\hline 2 & A2 & A2 & 0.4472 & 0.3381 & 0.4949 & 0.3536 \\
\hline 3 & A3 & A3 & 0.4472 & 0.5071 & 0.4949 & 0.3536 \\
\hline 4 & A4 & A4 & 0.4472 & 0.5071 & 0.4124 & 0.3536 \\
\hline 5 & A5 & A5 & 0.4472 & 0.5071 & 0.4124 & 0.7071 \\
\hline
\end{tabular}

Gambar 5. Matrik Rating Kinerja Ternormalisasi. 


\begin{tabular}{|c|c|c|c|}
\hline \multicolumn{4}{|c|}{ Solusi Ideal positif $\left(\mathrm{A}^{+}\right)$} \\
\hline \multicolumn{4}{|l|}{ Krlterla } \\
\hline IPK & KRP & Sert|flkas| & Kejuaraan \\
\hline $\mathrm{y}_{1}^{+}$ & $\mathrm{y}_{2}^{+}$ & $\mathrm{y}_{3}^{+}$ & $\mathrm{y}_{4}^{+}$ \\
\hline 1.7888 & 1.5213 & 0.9898 & 0.7071 \\
\hline \multicolumn{4}{|c|}{ Solusi Ideal negatif ( $\left.A^{-}\right)$} \\
\hline \multicolumn{4}{|l|}{ Krlterla } \\
\hline IPK & KRP & Sertlflkas| & Kejuaraan \\
\hline$y_{1}^{-}$ & $y_{2}^{-}$ & $y_{3}^{-}$ & $\mathrm{y}_{4}^{-}$ \\
\hline 1.7888 & 1.0143 & 0.8248 & 0.3536 \\
\hline
\end{tabular}

Gambar 6. Hasil Perhitungan Solusi Ideal Positif dan Negatif.

Nilai Preferensi $\left(\mathrm{V}_{\mathrm{i}}\right)$
\begin{tabular}{|l|l|l|l|}
\hline No & Alternatlf & Nama & $\mathbf{V}_{\mathbf{i}}$ \\
\hline 1 & A1 & A1 & 0 \\
\hline 2 & A2 & A2 & 0.066526364661 \\
\hline 3 & A3 & A3 & 0.69464520799416 \\
\hline 4 & A4 & A4 & 0.62811884333316 \\
\hline 5 & A5 & A5 & 0.933473635339 \\
\hline
\end{tabular}

Gambar 7. Hasil Preferensi Akhir.

\section{KESIMPULAN DAN SARAN}

Dari hasil penelitian, dapat disimpulkan bahwa metode TOPSIS merupakan metode yang mudah digunakan untuk pengambilan keputusan dengan kondisi kriteria yang lebih dari satu. Penentuan bobot atas kriteria yang ada, akan menentukan atau mempengaruhi hasi preferensi.

Berdasarkan paparan hasil penelitian yang telah dijelaskan maka ada beberapa hal yang dapat dijadikan bahan penelitian selanjutnya, yaitu jarak / range kriteria yang lebih kecil untuk kriteria IPK dan nilai KRP, serta dimungkinkan untuk menerapkan metode lain dalam proses pembobotan.

\section{DAFTAR PUSTAKA}

[1] C. Hwang and Y. Lai, A New Approach for Multiple Objective, Comput. Oper. Res., vol. 20, no. 8, pp. 889-899, 1993.

[2] M. M. Keshtkar, Performance analysis of a counter flow wet cooling tower and selection of optimum operative condition by MCDM-TOPSIS method, Appl. Therm. Eng., vol. 114, pp. 776-784, 2017.

[3] K. Jha, R. Kumar, K. Verma, B. Chaudhary, Y. K. Tyagi, and S. Singh, Application of modified TOPSIS technique in deciding optimal combination for bio-degradable composite, Vacuum, vol. 157, pp. 259-267, 2018. 
[4] V. Balioti, C. Tzimopoulos, and C. Evangelides, Multi-Criteria Decision Making Using TOPSIS Method Under Fuzzy Environment. Application in Spillway Selection, Proceedings, vol. 2, no. 11, p. 637, 2018. 